\title{
Variation in the quality characteristics of different rice bran cultivar extracts upon hexane or supercritical fluid extraction
}

\author{
Jung-Min Kim ${ }^{1}$, Yul-Ri Gu${ }^{1}$, Bo-Yeon Park ${ }^{1}$, Joo-Heon Hong ${ }^{1}$, Kwang-Sup Youn ${ }^{1,2 *}$ \\ ${ }^{1}$ Department of Food Science and Technology, Daegu Catholic University, Gyeongsan 38430, Korea \\ ${ }^{2}$ Institute of Food Science and Technology, Daegu Catholic University, Gyeongsan 38430, Korea
}

\section{품종에 따른 쌀 미강의 핵산 및 초임계 유체 추출물의 품질특성}

\author{
김정민 ${ }^{1} \cdot$ 구율리 $^{1} \cdot$ 박보연 $^{1} \cdot$ 홍주헌 $^{1} \cdot$ 윤광섭 $^{1,2 *}$ \\ ${ }^{1}$ 대구가톨릭대학교 식품공학과, ${ }^{2}$ 대구가톨릭대학교 식품과학연구소
}

\begin{abstract}
The quality characteristic properties of rice bran extracts from a range of cultivars (i.e., Bukkyeong 2012-2, Hanahreum, and Jasmin 85) that had been prepared using different extraction methods (i.e., supercritical fluid or hexane) were investigated. The $\mathrm{pH}$ values of the hexane rice bran extracts were higher than those of the supercritical fluid extracts, while the $L$ values, a values, and $b$ values were found to be $43.70-56.51,-1.73-0.80$, and $-0.08-9.97$, respectively. In addition, the iodine values of the supercritical fluid rice bran extracts (58.46-59.30 g) were higher than those of the hexane extracts (41.30-42.80 g), while the acid values of the Jasmin 85 cultivars obtained from the supercritical fluid and hexane rice bran extracts were 23.66 and $2.15 \mathrm{mg} / \mathrm{g}$, respectively, which were lower values than those obtained for the other extracts. Furthermore, the peroxide values of the bran extracts were $3.33-70.06 \mathrm{meq} / \mathrm{kg}$, where the values obtained for the supercritical fluid rice bran extracts $(44.71-70.06 \mathrm{meq} / \mathrm{kg})$ were higher than those of the hexane extracts $(3.33-35.67 \mathrm{meq} / \mathrm{kg})$. In the case of the TBA value, the supercritical fluid rice bran extracts gave higher values $(68.23-124.55 \mathrm{mg} / \mathrm{kg})$ than the hexane extracts $(5.33-97.16 \mathrm{mg} / \mathrm{kg})$. Moreover, the total tocopherol contents of the supercritical fluid and hexane rice bran extracts were 10.20 and $10.63 \mathrm{~g} / 100 \mathrm{~g}$ for the Bukkyeong 2012-2 cultivar, 8.30 and $7.35 \mathrm{~g} / 100 \mathrm{~g}$ for the Hanahreum cultivar, and 4.85 and $6.94 \mathrm{~g} / 100 \mathrm{~g}$ for the Jasmin 85 cultivar. The fatty acid contents of the rice bran extracts decreased in the order of oleic acid, linoleic acid, then palmitic acid, and the unsaturated fatty acid contents of the Hanahreum rice bran extracts $(81.21$ and $80.60 \%)$ were higher than those of the Bukkyeong 2012-2 and Jasmin 85 rice bran extracts. Our results therefore indicate that the quality characteristics of the supercritical fluid Bukkyeong 2012-2 and Hanahreum rice bran extracts render them useful for application in the food industry.
\end{abstract}

Key words : rice bran, supercritical fluid extraction, hexane extraction, cultivars, quality characteristics

\section{서 론}

미강(rice bran)은 현미에서 정백미로 도정하는 과정에서 생기는 과피, 종피, 호분층 등의 분쇄혼합물로, 미강의 구성

*Corresponding author. E-mail : ksyoun@cu.ac.kr

Phone : 82-53-850-3209, Fax : 82-53-850-3209

Received 20 September 2019; Revised 03 October 2019; Accepted 07 October 2019.

Copyright (c) The Korean Society of Food Preservation. All rights reserved.
성분은 단백질 $12-16 \%$, 지방 $16-22 \%$ 및 섬유소 8-12\% 등으 로 구성되어 있다(1). 지방산의 $70 \%$ 이상이 올레인산, 리놀 렌산, 리놀렌산의 불포화 지방산으로 이루어져 있을 뿐만 아니라, 비타민E, 식이섬유 등 다양한 유효성분들이 함유되 어 있다(2). 또한 미강은 vitamin $\mathrm{B}$ 군, vitamin $\mathrm{E}, \mathrm{Ca}, \mathrm{P}, \mathrm{Mg}$, $\mathrm{Fe}$ 와 같은 미네랄과 $\gamma$-oryzanol, $\alpha$-tocotrienol, $\beta$-tocopherol, y-tocopherol, $\delta$-tocopherol와 같은 항산화 물질이 다량 함유 되어 천연 항산화제로 작용하며(3), 염증 반응 억제 활성(4), 혈압상승 억제 작용(5) 및 혈중 콜레스테롤 저하(6) 인슐린 개선효과(7), 항스트레스 효과(8), 항암효과(9), 종양억제 
(10) 등 다양한 생리활성을 나타내고 있어 건강 유지와 질병 예방을 위해 이들 성분을 활용하고자 하는 연구가 진행되고 있다.

식생활의 다양화와 고급화로 인한 쌀 소비량 감소로 과 잉 생산의 문제, 식품의 기호성 증진을 위해 과거보다 더욱 정교해지는 곡류의 도정과정으로 인해 미강의 발생량은 계속 증가될 것으로 예측되고 있어 미강을 이용한 식품소재 로서의 연구 개발이 지속적으로 이루어지고 있다 $(11,12)$. 하지만 우수한 영양과 기능적 가치를 함유하고 있음에도 불구하고 미강은 식품의 식미를 떨어뜨리고 저장성이 매우 낮아 연간 40 만 톤의 미강 생산량 중 약 $20-30 \%$ 정도만이 미강 추출물 추출의 원료로 쓰이고 나머지는 사료나 유기질 비료로 이용되고 있어 효과적인 활용에는 어려움이 있는 실정이다 $(13,14)$. 반면 국외에서는 미강의 영양학적, 기능 적 특성을 고려한 식품 개발을 꾸준히 하여 고섬유질 빵, 머핀, 쿠키, 크래커 등 구운 제품에 많이 활용하고 있으며 (15), 일본, 미국 등의 나라에서는 영양보충용 식품, 제과제 빵용 소재 등으로 개발해 왔으며, 미강을 활용한 제품들 중에서 최근 관심을 받고 있는 분야는 숙취해소, 혈중 콜레 스테롤 감소, 간기능 개선, 영양보충용 보조식품 등이 있다 (10). 최근 국내에서는 미강를 이용한 식품 연구에는 제과제 빵 특성연구(17), 발효쌀겨를 이용한 반죽의 제빵 특성(18) 이 연구되고 있다.

핵산을 이용한 용매 추출법은 용제를 사용하기 때문에 물질의 품질변화가 일어나지 않으며, 식품공업에서 널리 이용되고 있는 방법이나 독성을 나타내는 헥산을 허용치 이하로 낮추기 위한 정제과정이 필요하다(19). 이산화탄소 를 이용한 초임계 유체 추출법은 물질의 기상과 액상의 상경계지점인 critical point 이상의 압력과 온도를 설정해 줌으로써 액상의 용해력과 기상의 확산계수와 점도의 특성 을 지니게 하여 신속한 추출과 선택적 추출이 가능하게 하는 방법이다(20). 초임계 유체를 이용하여 유지 및 지용성 생리활성 물질을 추출 또는 농축하는 방법을 사용할 수 있으며, 추출 또는 농축 후 용매를 제거하는 공정이 필요 없는 친환경적 방법이며, 또한 비교적 저온, 고압에서 이루 어지므로 목적 물질의 파괴 및 변화가 거의 없다는 장점이 있다(21).

따라서 본 연구에서는 쌀 도정과정에서 부산물로 배출되 는 미강의 이용가치를 향상시키고자 핵산 및 초임계 유체 추출법을 이용하여 쌀 품종에 따른 품질특성을 검토하여 미강의 활용을 위한 기초자료를 제공하고자 하였다.

\section{재료 및 방법}

\section{실험재료}

본 연구에 사용한 미강은 쌀 품종에 따라 3종(Bukkyeong
2012-2(북경), Jasmin 85(자스민) 및 Hanahreum(한아름))을 사용하였으며, 2017년 수확하여 정미기(LH-5000M, Hwangso Co., Daegu, Korea)로 10분도로 정미하고 얻어진 미강을 국립식량과학원으로부터 제공받아 사용하였다. 미강은 분 쇄기(RT-04, Hanli Co., Sejong, Korea)로 분쇄하여 60 mesh 표준망체(Chung Gye Sang Cong Sa, Seoul, Korea)를 통과한 분말을 $-20^{\circ} \mathrm{C}$ 이하 암소에서 보관하면서 추출용 시료로 사 용하였다.

\section{추출방법에 따른 미강 추출물 제조}

핵산을 이용한 추출방법은 미분쇄한 미강 분말과 핵산을 1:10(w/v) 비율로 혼합한 다음 shaking incubator(BS-31, Jeio Tech., Daejeon, Korea)에서 $170 \mathrm{rpm}$ 으로 24시간 진탕·추출 하였다. 불순물을 제거하기 위해 여과한 다음 감압농축기 (Model N-1N, Eyela Co., Tokyo, Japan)를 이용하여 핵산을 모두 제거하여 미강 추출물을 제조하였다. 초임계를 이용 한 추출방법은 미분쇄한 미강 분말을 추출압력 $400 \mathrm{bar}$, 추출온도 $50^{\circ} \mathrm{C}$ 및 $\mathrm{CO}_{2}$ 유속 $20 \mathrm{~mL} / \mathrm{min}$ 조건하에서 4 시간 추출하였다. 품종에 따라 얻어진 미강 추출물 3 종과 비교하 기 위해 대조군으로 시중에 판매 중인 식용유(CJ Cheil Jedang, Incheon, Korea)와 미강 추출물(JCY, Seongnam, Korea)을 같이 분석하였다.

\section{$\mathrm{pH}$ 및 색도 측정}

미강 추출물의 $\mathrm{pH}$ 는 $\mathrm{pH}$ meter(S220, Mettler Toledo, Schwerzenbach, Switzerland)로 3회 반복 측정하여 그 평균 값과 표준편차로 표기하였다. 색도는 표준색도 $\mathrm{Y}=86.6$, $\mathrm{x}=0.3160, \mathrm{y}=0.3214$ 로 보정된 chromameter(CR-400, Minolta Co., Osaka, Japan)를 이용하여 측정하였으며, L값 (brightness), a 값(redness-greenness), b값(yellowness-blueness) 을 3회 반복 측정하여 평균치로 나타내었다.

\section{산가 및 과산화물가}

산가 및 과산화물가 측정은 식품의약품안전처 식품공전 의 식품성분시험법에 따라 수행하였다(22). 산가측정은 시 료를 마개달린 삼각플라스크에 취한 후, ethanol : ethylether (1 : 2, v/v) 혼액 $100 \mathrm{~mL}$ 를 넣고 용해시킨다. 이를 phenolphthalein 용액을 지시약으로 하고 엷은 홍색이 30초 간 지속할 때까지 $0.1 \mathrm{~N}$ ethanolic $\mathrm{KOH}$ 용액으로 적정하였 다. 과산화물가 측정은 시료를 acetic acid : chloroform (3 : 2, v/v) $25 \mathrm{~mL}$ 를 가하여 혼합한 후 potassium iodide 용액 $1 \mathrm{~mL}$ 을 섞은 다음 암소에서 10 분간 반응시키고 증류수 $30 \mathrm{~mL}$ 를 넣고 교반하였다. Starch solution $1 \mathrm{~mL}$ 를 지시약으 로 하여 $0.01 \mathrm{~N}$ sodium thiosulfate 용액으로 적정하였다.

\section{요오드가 및 TBA가}

요오드가는 미강 추출물 $0.5 \mathrm{~g}$ 을 용매 $\left(\mathrm{CCl}_{4}\right) 10 \mathrm{~mL}$ 에 
완전히 녹인 뒤 Wijs's reagent $25 \mathrm{~mL}$ 첨가 후 1 시간 암소 방치한 후, potassium iodide $20 \mathrm{~mL}$, 증류수 $10 \mathrm{~mL}$ 를 차례로 가한 후 $0.1 \mathrm{~N}$ sodium thiosulfate로 적정하였다(23). TBA가 는 Tarladgis(24)의 방법에 의해 미강 추출물 $0.5 \mathrm{~g}$ 에 benzene $5 \mathrm{~mL}$ 를 첨가하여 볼텍스 후 TBA reagent $5 \mathrm{~mL}$ 첨가한 후 5 분 방치하여 분액여두로 이동, 하층부 분리하여 $95^{\circ} \mathrm{C}$, 30 분 반응시킨다. 그 후 10 분 냉각하여 분광광도계 (Ultrospec 2100pro, Biochrom Ltd., Cambridge, UK)를 이용 하여 $530 \mathrm{~nm}$ 에서 측정하였다.

\section{총 토코페롤 함량}

품종별 미강 추출물의 토코페롤 함량은 Lee 등(25)의 방 법에 기초하여 측정하였다. 미강추출물 $1 \mathrm{~g}$ 에 $12 \%$ ethanolic $\mathrm{KOH} 20 \mathrm{~mL}$ 를 넣고 $60^{\circ} \mathrm{C}$ 항온수조에서 90 분간 반응시킨 뒤 Ice bath에 옮겨 신속히 냉각하였다. 3차 증류수 $20 \mathrm{ml}$ 와 $\mathrm{n}$-hexane $10 \mathrm{~mL}$ 를 첨가하여 30 분 동안 반응시킨 후 $\mathrm{n}$-hexane은 회수하는 과정을 3 회 반복추출하였다. 분석조 건은 HPLC(Waters 2695, Waters Co., Miliford, MA, USA)를 이용하였으며, 컬럼은 Kinetex F5 column $(4.6 \times 150 \mathrm{~mm})$, 용 매조성은 methanol을 유속은 $0.8 \mathrm{~mL} / \mathrm{min}$ 조건으로 흘려주 고, 온도는 $40^{\circ} \mathrm{C}$ 에서 실행하였다. 표준물질로는 $\mathrm{a}$ -tocopherol, $\beta$-tocopherol, $\gamma$-tocopherol, $\delta$-tocopherol을 Sigma-Aldrich Co.로부터 구입하여 표준용액을 제조하였으 며, peak area의 실측치와 표준물질의 농도간 계산에 의해 총 토코페롤 함량을 산출하였다

\section{지방산 조성 분석}

미강 추출물의 지방산 분석은 $\mathrm{AOAC}$ 방법(26)에 따라 methyl ester화 시킨 후 $\mathrm{GC}$ 로 분석하였다. 즉, 시료 추출물
$1 \mathrm{~g}$ 에 5\% pyrogallol, ethanol $2 \mathrm{~mL}$ 를 첨가하여 혼합한 후 $8.3 \mathrm{M} \mathrm{HCl} 10 \mathrm{~mL}$ 를 첨가하여 $80^{\circ} \mathrm{C}$ 항온수조에서 40 분간 가열 반응시켰다. Petroleum ether 및 ethyl ether를 이용하여 추출한 후 ether를 증발시켜 지방산 분석 시료로 하였다. GC(GC-2010 plus, Shimadzu, Kyoto, Japan), 컬럼은 $\mathrm{SP}-2560(100 \mathrm{~m} \times 0.25 \mathrm{~mm}, 0.2 \mu \mathrm{m})$ 를 사용하였다. 컬럼의 온도는 $100-240^{\circ} \mathrm{C}$ 로 점차 상승하도록 하였으며, 이때 carrier gas는 helium(70 kpa)을 make-up gas는 질소를 사용 하였다. 동정은 표준지방산 methyl ester mixture(Sigma Chemical Co., St. Louis, MO, USA)와 retention time을 비교 하여 확인하였으며, 조성비율은 각 peak의 면적을 상대적 인 백분율로 나타내었다.

\section{통계처리}

모든 실험결과는 IBM SPSS Statistics(19.0, IBM Corp., Armonk, NY, USA)를 이용한 분산분석(ANOVA)을 실시하 였고 각 측정 평균값의 유의성( $\mathrm{p}<0.05)$ 은 Duncan's multiple range test를 실시하여 검정하였다.

\section{결과 및 고찰}

\section{$\mathrm{pH}$ 및 색도}

추출방법(핵산, 초임계)에 따른 미강 추출물은 북경, 자 스민, 한아름미를 사용하였으며, 쌀품종에 따른 아밀로스 함량을 측정하였다(data not showed). 아밀로스 함량은 품종 에 따라 북경은 $34.12 \%$, 자스민은 $25.76 \%$ 로, 한아름은 $22.27 \%$ 로 나타났으며, 일반적으로 쌀은 아밀로스 함량에 따라 분류를 하는데 고아밀로스는 $25 \%$ 이상, 중간 아밀로

Table 1. $\mathrm{pH}$ and color value of rice bran extracts prepared by different extraction methods and cultivars

\begin{tabular}{|c|c|c|c|c|}
\hline \multirow{2}{*}{ Sample ${ }^{1)}$} & \multirow{2}{*}{$\mathrm{pH}$} & \multicolumn{3}{|c|}{ Color value } \\
\hline & & $\mathrm{L}$ & $\mathrm{a}$ & $\mathrm{b}$ \\
\hline SO & $5.07 \pm 0.08^{(2)}$ & $55.27 \pm 0.07^{\mathrm{a}}$ & $0.06 \pm 0.01^{\mathrm{a}}$ & $-0.08 \pm 0.07^{g}$ \\
\hline S-RB & $5.39 \pm 0.11^{\mathrm{c}}$ & $55.02 \pm 0.04^{\mathrm{a}}$ & $-1.02 \pm 0.02^{\mathrm{bc}}$ & $2.91 \pm 0.03^{f}$ \\
\hline S-BRB & $3.62 \pm 0.22^{f}$ & $44.26 \pm 0.16^{\mathrm{d}}$ & $-1.15 \pm 0.04^{\mathrm{de}}$ & $7.47 \pm 0.09^{\mathrm{bc}}$ \\
\hline S-JRB & $3.55 \pm 0.23^{\mathrm{f}}$ & $44.22 \pm 0.36^{\mathrm{d}}$ & $-1.61 \pm 0.13^{f}$ & $9.34 \pm 1.06^{a}$ \\
\hline S-HRB & $2.66 \pm 0.15^{\mathrm{g}}$ & $43.70 \pm 0.07^{\mathrm{d}}$ & $-1.07 \pm 0.03^{\text {cd }}$ & $7.07 \pm 0.10^{\text {cd }}$ \\
\hline $\mathrm{HO}$ & $4.54 \pm 0.10^{\mathrm{e}}$ & $56.51 \pm 0.23^{a}$ & $-0.06 \pm 0.04^{\mathrm{a}}$ & $0.35 \pm 0.02^{\mathrm{g}}$ \\
\hline $\mathrm{H}-\mathrm{RB}$ & $5.98 \pm 0.18^{\mathrm{a}}$ & $56.07 \pm 0.15^{\mathrm{a}}$ & $-1.73 \pm 0.04^{\mathrm{de}}$ & $5.08 \pm 0.15^{\mathrm{f}}$ \\
\hline H-BRB & $5.70 \pm 0.03^{b}$ & $49.58 \pm 0.22^{\text {cd }}$ & $0.80 \pm 0.06^{\mathrm{a}}$ & $9.52 \pm 0.13^{b}$ \\
\hline H-JRB & $5.80 \pm 0.01^{\mathrm{ab}}$ & $46.18 \pm 0.18^{\mathrm{bc}}$ & $-1.13 \pm 0.02^{\mathrm{e}}$ & $9.97 \pm 0.20^{e}$ \\
\hline H-HRB & $5.20 \pm 0.03^{\mathrm{cd}}$ & $45.54 \pm 0.29^{b}$ & $-0.87 \pm 0.04^{b}$ & $9.43 \pm 0.24^{\text {de }}$ \\
\hline
\end{tabular}

\footnotetext{
${ }^{1)}$ SO, superctitical extract of commercial soybean oil; S-RB, superctitical extract of commercial rice bran oil; S-BRB, superctitical extract of Bukkyeong 2012-2 rice bran; S-JRB, superctitical extract of Jasmin 85 rice bran; S-HRB, superctitical extract of hanahreum rice bran; HO, hexane extract of commercial soybean oil; H-RB, hexane extract of commercial rice bran oil; H-BRB, hexane extract of Bukkyeong 2012-2 rice bran; H-JRB, hexane extract of Jasmin 85 rice bran; H-HRB, hexane extract of hanahreum rice bran.

${ }^{2)}$ Means \pm SD ( $n=3$ ) with different letters within a column (a-g) indicate significant differences $(p<0.05$ ).
} 
스는 20-25\%, 저아밀로스는 7-20\%로 분류된다(27). 아밀로 스 함량의 측정방법에 따른 약간의 편차를 가지며 본 연구 의 결과 북경, 자스민은 고아밀로스, 한아름은 중간 아밀로 스로 분류할 수 있다. 추출방법에 따른 미강 추출물의 $\mathrm{pH}$ 및 색도는 Table 1과 같다. 미강 추출물의 $\mathrm{pH}$ 는 2.66-5.98로, 핵산 추출한 시판 미강 추출물(H-RB)에서 5.98 로 가장 높게 측정되었으며, 초임계 유체 추출한 한아름 미강 추출물 (S-HRB)에서 2.66으로 가장 낮게 측정되었다. 초임계 미강 추출물의 $\mathrm{pH}$ 는 시판 미강유(S-RB)가 5.39로 높게 나타났으 며, 초임계 유체 추출한 북경, 자스민 및 한아름 미강 추출물 이 각각 $3.62,3.55$ 및 2.66 로 나타났다. Shin 등(28)의 볶은 미강의 품질특성 연구에서는 $\mathrm{pH}$ 는 5.78-5.43으로 나타났으 며, 미강 첨가량이 증가할수록 $\mathrm{pH}$ 가 감소하는 경향이 나타 내었다고 보고하였다.

미강 추출물의 $\mathrm{L}$ 값은 43.70-56.51로, 초임계 유체 및 핵산 추출한 식용유 추출물에서 각각 $55.27,56.51$ 로 가장 높게 나타났으며, 품종에 따른 초임계 추출한 미강 추출물 (43.70-44.26)은 핵산 추출한 미강 추출물(45.54-49.58)보다 낮게 나타났다. 또한 초임계 유체 및 핵산 추출한 한아름 미강 추출물(S-HRB, H-HRB)에서 각각 43.70, 45.54로 가장 낮게 나타났다. a값은 -1.73-0.80으로 나타났으며, 품종에 따라서는 핵산 추출한 북경 미강 추출물(H-BRB)에서 0.80 로 가장 높게 나타났으며, 초임계 유체 추출한 자스민 미강 추출물(S-JRB)에서 -1.61로 가장 낮게 나타났다. $\mathrm{b}$ 값은 -0.08-9.97로 나타났으며, 품종에 따라서는 핵산 추출한 자 스민 미강 추출물(H-JRB)에서 9.97로 가장 높게 나타났으 며, 초임계 유체 추출한 한아름 미강 추출물(S-HRB)에서 7.07로 가장 낮게 나타났다. Shin 등(28)의 볶은 미강을 첨가 한 쌀빵의 품질특성 연구에서 볶은 미강 분말 첨가량이 증가할수록 $\mathrm{L}$ 값이 감소하고, $\mathrm{b}$ 값은 증가하였다고 보고하
였으며, Hwang 등(29)은 발효미강 반죽의 품질특성 연구에 서 미강 분말 첨가량이 증가할수록 $\mathrm{L}$ 값은 감소하고, $\mathrm{b}$ 값은 증가한다고 보고하여 본 연구결과와 유사하였다.

\section{요오드가, 산가, 과산화물가 및 TBA가}

추출방법(핵산, 초임계)에 따른 미강 추출물의 요오드가, 산가, 과산화물가 및 TBA가는 Table 2 와 같다. 요오드가는 식물성 유지에 이중결합이 얼마나 있는가를 측정하는 것으 로(30), 이중결합의 수가 많으면 탄소 체인이 구조적으로 꺾이기 때문에 굳게 되는 분자구조로 될 가능성이 적어 저온에서 액상으로 존재하게 된다(31). 따라서 핵산 추출한 시판 식용유(HO) 및 시판 미강유(H-RB)의 요오드가는 각 각 $46.50 \mathrm{~g}$ 및 $43.80 \mathrm{~g}$ 으로 품종을 달리한 미강 추출물 3종 (41.30-42.80 g)보다 높게 나타났다. 초임계 추출한 미강 추출물의 요오드가의 경우, 한아름(S-HRB), 북경미 (S-BRB), 자스민(S-JRB)에서 각각 $59.30,58.88,58.46 \mathrm{~g}$ 으 로 나타나 핵산 추출한 미강 3종 추출물(41.30-42.80)보다 높게 나타나 온도가 감소할 경우 초임계 유체 추출한 미강 추출물이 상대적으로 유동성이 우수할 것으로 판단된다.

산가는 유지의 정제가 불안정한 경우나 보존 및 사용상 태가 불량한 경우, 유지가 가수분해되어 유리된 지방산의 양은 증가하게 되며, 유리지방산의 생성은 유지의 자동산 화를 촉진하여 제품의 품질 및 관능적으로 좋지 않은 영향 을 미치게 된다(32). 핵산 추출한 시판 식용유(HO) 및 미강 추출물(H-RB)은 검출되지 않았으며, 초임계 유체 추출한 식용유(SO) 및 시판 미강 추출물(S-RB)은 모두 $0.09 \mathrm{mg} / \mathrm{g}$ 으 로 낮게 나타났다. 품종에 따른 핵산 추출한 미강 추출물의 산가는 자스민 추출물(H-JRB)에서 $2.15 \mathrm{mg} / \mathrm{g}$ 으로 낮게 나 타났으며, 그 다음으로 북경 추출물(H-BRB), 한아름 추출

Table 2. Iodine value, acid value, peroxide value and TBA value of rice bran extracts prepared by different extraction methods and cultivars

\begin{tabular}{ccccc}
\hline Sample $^{\mathrm{l})}$ & Iodine value $(\mathrm{g})$ & Acid value $(\mathrm{mg} / \mathrm{g})$ & Peroxide value $(\mathrm{meq} / \mathrm{kg})$ & $\mathrm{TBA}$ value $(\mathrm{mg} / \mathrm{kg})$ \\
\hline SO & $59.56 \pm 0.33^{\mathrm{2} 2)}$ & $\mathrm{ND}^{3)}$ & $52.70 \pm 0.06^{\mathrm{b}}$ & $68.24 \pm 0.23^{\text {cd }}$ \\
S-RB & $57.36 \pm 0.73^{\mathrm{a}}$ & $\mathrm{ND}$ & $59.00 \pm 0.03^{\mathrm{b}}$ & $118.96 \pm 1.05^{\mathrm{a}}$ \\
S-BRB & $58.88 \pm 0.57^{\mathrm{a}}$ & $30.21 \pm 2.59^{\mathrm{b}}$ & $44.71 \pm 0.18^{\mathrm{b}}$ & $97.11 \pm 0.63^{\mathrm{b}}$ \\
S-JRB & $58.46 \pm 0.51^{\mathrm{a}}$ & $23.66 \pm 0.86^{\mathrm{c}}$ & $70.06 \pm 0.06^{\mathrm{a}}$ & $124.55 \pm 1.16^{\mathrm{a}}$ \\
S-HRB & $59.30 \pm 0.46^{\mathrm{a}}$ & $94.92 \pm 1.17^{\mathrm{a}}$ & $52.30 \pm 0.12^{\mathrm{c}}$ & $114.17 \pm 0.28^{\mathrm{a}}$ \\
\hline HO & $46.50 \pm 0.50^{\mathrm{b}}$ & $0.09 \pm 0.01^{\mathrm{g}}$ & $31.67 \pm 1.15^{\mathrm{d}}$ & $60.72 \pm 7.19^{\mathrm{d}}$ \\
H-RB & $43.80 \pm 0.01^{\mathrm{b}}$ & $0.09 \pm 0.01^{\mathrm{g}}$ & $35.67 \pm 1.53^{\mathrm{d}}$ & $35.33 \pm 3.89^{\mathrm{e}}$ \\
H-BRB & $42.80 \pm 0.07^{\mathrm{b}}$ & $9.63 \pm 0.49^{\mathrm{e}}$ & $17.67 \pm 4.16^{\mathrm{e}}$ & $77.33 \pm 18.33^{\mathrm{c}}$ \\
H-JRB & $42.70 \pm 0.30^{\mathrm{b}}$ & $2.15 \pm 0.32^{\mathrm{f}}$ & $3.33 \pm 1.73^{\mathrm{f}}$ & $97.16 \pm 3.75^{\mathrm{b}}$ \\
H-HRB & $41.30 \pm 1.04^{\mathrm{b}}$ & $18.89 \pm 1.01^{\mathrm{d}}$ & $11.33 \pm 1.73^{\mathrm{e}}$ & $71.33 \pm 13.86^{\mathrm{cd}}$ \\
\hline
\end{tabular}

${ }^{11}$ SO, superctitical extract of commercial soybean oil; S-RB, superctitical extract of commercial rice bran oil; S-BRB, superctitical extract of Bukkyeong 2012-2 rice bran; S-JRB, superctitical extract of Jasmin 85 rice bran; S-HRB, superctitical extract of hanahreum rice bran; HO, hexane extract of commercial soybean oil; H-RB, hexane extract of commercial rice bran oil; H-BRB, hexane extract of Bukkyeong 2012-2 rice bran; H-JRB, hexane extract of Jasmin 85 rice bran; H-HRB, hexane extract of hanahreum rice bran.

${ }^{2)}$ Means \pm SD ( $n=3$ ) with different letters within a column $(\mathrm{a}-\mathrm{g})$ indicate significant differences $(\mathrm{p}<0.05)$.

${ }^{3)} \mathrm{ND}$, Not detected 
물에서 각각 $9.63 \mathrm{mg} / \mathrm{g}, 18.89 \mathrm{mg} / \mathrm{g}$ 으로 나타났다. 초임계 추출한 미강 추출물은 품종에 따라서는 자스민(S-JRB), 북 경(S-BRB), 한아름(S-HRB) 미강 추출물 순으로 각각 23.66, $30.21,94.92 \mathrm{mg} / \mathrm{g}$ 으로 나타나 핵산 추출한 미강 추출물보다 높게 나타났다. Kim 등(33)의 추출방법에 따른 인삼씨유의 연구에서도 용매추출물의 산가가 초임계 유체 추출물에 비해 유의적으로 낮게 나타나 본 연구결과와 유사하였다.

과산화물가는 유지의 산패에서 생기는 hydroperoxide 함 량을 측정하여 산패정도를 측정하는 것으로(34), 핵산 추출 한 시판 미강유 추출물 $(\mathrm{H}-\mathrm{RB})$ 및 초임계 추출한 시판 미강 추출물(S-RB)은 각각 $35.67,59.00 \mathrm{meq} / \mathrm{kg}$ 으로 미강추출물 보다 높게 나타났다. 품종에 따른 핵산 추출한 미강 추출물 의 과산화물가는 자스민 추출물(H-JRB)에서 $3.33 \mathrm{meq} / \mathrm{kg}$ 으로 가장 낮게 나타났으며, 북경 추출물(H-BRB), 한아름 추출물(H-HRB)에서 각각 $11.33 \mathrm{meq} / \mathrm{kg}, 17.67 \mathrm{meq} / \mathrm{kg}$ 으로 나타났다. 초임계 유체 추출한 미강 추출물은 품종에 따라 서는 북경(S-BRB), 한아름(S-HRB), 자스민(S-JRB) 미강 추 출물 순으로 각각 $44.71,52.30,70.06 \mathrm{meq} / \mathrm{kg}$ 으로 나타나 핵산 추출한 미강 추출물보다 높게 나타났다. Kim 등(33)의 추출방법에 따른 인삼씨유의 연구에서 과산화물가는 저장 기간에 따라 증가하는 경향을 나타내었으며, 저장 28 일째 용매추출물, 초임계 유체 추출물의 과산화물가는 각각 $61.06,61.02 \mathrm{meq} / \mathrm{kg}$ 로 나타나 추출방법에 따른 큰 차이는 나타나지 않았다고 보고하였다.

유지의 산패가 진행되면 malonaldehyde가 생성되며 이때 TBA reagent와 반응한 적색의 생성물을 측정하여 산패의 정도를 확인할 수 있다(24). 핵산 추출한 시판 미강 추출물 $(\mathrm{H}-\mathrm{RB})$ 은 $35.33 \mathrm{mg} / \mathrm{kg}$ 으로 나타나 핵산 미강 추출물 중 가장 낮게 측정되었다. 품종에 따른 핵산 추출한 미강 추출 물의 TBA가는 한아름 미강 추출물(H-HRB)이 $71.33 \mathrm{mg} / \mathrm{kg}$ 으로 3 품종 중 가장 낮게 나타났으며, 북경 미강 추출물 (H-BRB)이 $77.33 \mathrm{mg} / \mathrm{kg}$, 자스민 미강 추출물(H-JRB)이 $97.16 \mathrm{mg} / \mathrm{kg}$ 으로 나타났다. 초임계 추출한 시판 식용유 추 출물(SO)의 TBA가는 $68.24 \mathrm{mg} / \mathrm{kg}$ 으로 초임계 추출물 중 가장 낮게 나타났으며, 품종에 따른 초임계 유체 추출한 미강 추출물의 TBA가는 북경, 한아름, 자스민 순으로 각각 $97.11,114,17,124.55 \mathrm{mg} / \mathrm{kg}$ 으로 나타나 초임계 추출한 시 판 미강 추출물(S-RB)은 $118.96 \mathrm{mg} / \mathrm{kg}$ 과 큰 차이가 없었다. 용매와 초임계 추출에 따른 추출물의 유지의 품질특성은 초임계 추출이 높게 나타났는데, 이는 $\mathrm{Botha}(35)$ 의 초임계 유체 추출한 아보카도 오일 연구에서는 $\mathrm{CO}_{2}$ 를 이용하여 초임계 유체 추출한 추출물에는 용해된 $\mathrm{CO}_{2}$ 가 포함되어 있어 시료의 산도에 영향을 주어 핵산으로 추출된 추출물보 다 산가 및 과산화물가가 높게 나타난다고 보고한 결과와 유사하였다.

\section{총 토코페롤 함량}

추출방법과 품종에 따른 미강 추출물의 총 토코페롤 함 량은 Fig. 1과 같다. 핵산 미강 내에 함유되어 있는 토코페롤 은 비타민 $\mathrm{E}$ 로 $\mathrm{a}, \beta, \gamma, \delta$ 가지 형태로 이루어져 있다. 토코 페롤은 항산화 작용을 하여 활성산소에 의하여 야기되는 지질의 손상을 억제하는 역할로 알려져 있다. 그 외에도 염증 조절 및 여러 가지 생화학적 기능과 질병 예방 측면의 기능이 있다(36). 초임계 유체 추출을 이용하여 추출한 북경 (S-BRB), 한아름(S-HRB) 및 자스민(S-JRB) 미강 추출물의 총 토코페롤 함량은 각각 $10.20,8.30$ 및 $4.85 \mathrm{~g} / 100 \mathrm{~g}$ 으로 나타났으며, 핵산으로 추출한 경우 품종에 따라서는 북경 (H-BRB), 한아름(H-HRB) 및 자스민(H-JRB) 미강 추출물 에서 각각 $10.63,7.35$ 및 $6.94 \mathrm{~g} / 100 \mathrm{~g}$ 으로 나타났으며, 북경 미강 추출물에서 가장 높은 함량을 나타내었다. $\mathrm{Gu}$ 등(37) 의 추출용매에 따른 미강 추출물의 항산화 연구에서는 북경 품종의 미강 추출물이 항산화 활성이 가장 높게 나타난 것으로 보고하였으며, 북경 미강 추출물의 높은 토코페롤 함량에 따른 것으로 판단된다. 또한 Chun 등(38)의 품종별 미강의 토코페롤 및 토코트리에놀 함량에 관한 연구에서 품종별 미강의 전체 비타민 $\mathrm{E}$ 함량은 $106.65-221.47 \mathrm{\mu g} / \mathrm{g}$ 으 로 나타났으며, Park 등(39)의 벼 품종별 미강의 총 비타민 $\mathrm{E}$ 함량은 $39.2 \mathrm{mg} / 100 \mathrm{~g}$ 로 나타나 본 실험에서 분석된 시료 의 토코페롤 함량이 더 높게 나타났다. 초임계 유체 및 핵산 을 이용하여 추출한 미강 추출물은 추출 방법에 따른 함량 차이는 있으나 품종에 따른 함량은 북경 미강 추출물이 가장 우수하고, 자스민 미강 추출물에서 가장 낮은 것으로 확인하였다. 이는 Chun 등(38)의 보고와 같이 미강 품종에 따라 토코페롤 및 토코트리에놀은 동족체( $\alpha, \beta, \gamma, \delta)$ 별로

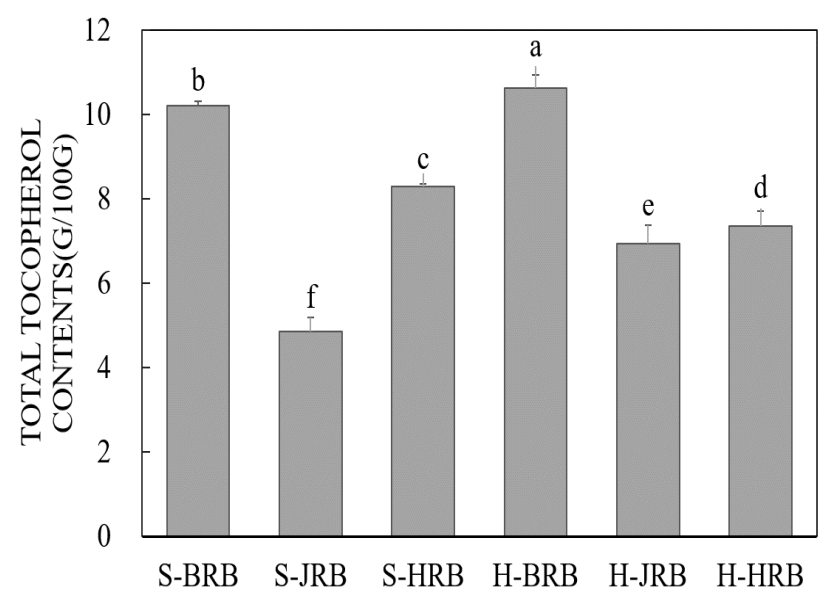

Fig 1. Total tocopherol contents of rice bran oil extracts prepared by different extraction methods and cultivars.

${ }^{1}$ S-BRB, superctitical extract of Bukkyeong 2012-2 rice bran; S-HRB, superctitical extract of han-ahreum rice bran; S-JRB, superctitical extract of Jasmin 85 rice bran; H-BRB, hexane extract of Bukkyeong 2012-2 rice bran; H-HRB, hexane extract of han-ahreum rice bran; H-JRB, hexane extract of Jasmin 85 rice bran.

${ }^{2}$ Means \pm SD ( $\mathrm{n}=3$ ) with different letters (a-f) above bars are significantly different by Duncan's multiple range test $(\mathrm{p}<0.05)$. 
분포 차이를 보였고, 이러한 토코페롤 및 토코트리에놀 함 량의 차이는 품종, 종자의 성숙도, 재배지역 및 기후상태 등에 따라 영향을 받는 것으로 알려져 있다(40).

\section{지방산 조성}

초임계 및 핵산을 이용하여 추출한 미강 추출물의 지방 산 조성을 분석한 결과 얻어진 총 12 종 지방산의 함량은 Table 3과 같다. 초임계 유체 및 핵산을 이용하여 추출한 미강 추출물은 oleic acid(C18:1), linoleic $\operatorname{acid}(\mathrm{C} 18: 2)$ 및 palmitic acid(C16:0)순으로 함량이 많았으며, 3 개의 지방산 이 전체 지방산의 $95 \%$ 정도의 비율을 나타내었다. Palmitic acid는 16.38-19.35\%로 나타났으며, 품종에 따라서는 한아 름 미강 추출물(S-HRB, H-HRB)에서는 각각 $16.38 \%$, $16.68 \%$ 로 측정되어 가장 낮게 측정되었으며, 자스민 미강 추출물(S-JRB, H-JRB)에서 각각 $19.29 \%, 19.38 \%$ 로 나타나 가장 함량이 높았다. Oleic acid(C18:1)는 42.73-47.35\%로 나타났으며, 초임계 및 핵산으로 추출한 자스민 미강 추출 물(S-JRB, H-JRB)이 각각 $47.35 \%, 47.12 \%$ 으로 나타나 함량 이 가장 높았다. Linoleic acid는 28.49-36.14\%로 나타났으 며, 품종에 따라서는 한아름 미강 추출물(S-HRB, H-HRB) 에서 각각 $36.14,35.28 \%$ 로 나타나 3 품종 중 linoleic acid 함량이 가장 높았다. 불포화지방산 함량은 한아름 미강 추 출물(S-HRB, H-HRB)에서는 $81.21 \%, 80.60 \%$ 로 나타나 불 포화지방산 함량이 가장 많았으며, 그 다음으로 북경 미강 추출물(S-BRB, H-BRB)에서는 $79.18 \%, 78.72 \%$ 로, 자스민 미강 추출물(S-JRB, H-JRB)에서는 $77.92 \%, 77.76 \%$ 로 나타
났다. 초임계 유체 및 핵산을 이용하여 추출한 미강 추출물 은 품종간에 지방산 조성은 차이가 나타났다. 추출방법에 따라서는 초임계 추출한 미강 추출물의 불포화지방산 함량 이 핵산 추출한 미강 추출물보다 높은 것으로 확인되었다. $\mathrm{Kim}$ 과 Lee(41)의 연구에서는 미강 추출물은 oleic acid와 linoleic acid가 각각 41.70과 $33.30 \%$ 를 차지하였고, palmitic acid, oleic acid 및 linoleic acid가 주요 지방산들로서 전체 지방산 조성의 $80 \%$ 이상을 차지한다고 보고하여 본 연구와 일치하였다. 또한 Lee 등(25)의 미강 추출물의 연구에서는 미강 추출물의 지방산 조성을 분석한 결과, 본 연구결과보 다 oleic acid는 낮고, linoleic acid 다소 높게 측정되었고, 불포화지방산 함량은 약 $82 \%$ 정도로 높게 측정되었는데, 이는 품종 및 추출방법 등에 따라 영향을 받는 것으로 판단 된다.

\section{요 약}

초임계와 핵산으로 추출한 미강 추출물의 활용성을 높이 고자 쌀 품종에 따른 품질특성으로 조사하였다. $\mathrm{pH}$ 의 경우, 초임계 유체 추출한 미강유에서 핵산 추출한 미강유보다 $\mathrm{pH}$ 가 낮게 측정되었다. 색도 중 $\mathrm{L}$ 값의 경우, 품종에 따른 초임계 유체추출한 미강 추출물은 핵산 추출한 미강 추출물 보다 낮게 나타났으며, 초임계 유체추출한 한아름 미강 추 출물(S-HRB)에서 43.70로 가장 낮게 나타났다. 품종에 따 른 초임계 유체 추출한 미강 추출물의 요오드가는

Table 3. Fatty acid composition of rice bran extracts prepared by different extraction methods and cultivars

\begin{tabular}{ccccccc}
\hline Fatty acids(\%) & S-BRB & S-JRB & S-HRB & H-BRB & H-JRB & H-HRB \\
\hline Myristic acid (C14:0) & 0.26 & 0.25 & 0.33 & 0.25 & 0.22 & 0.29 \\
Palmitic acid (C16:0) & 18.08 & 19.29 & 16.38 & 17.84 & 19.38 & 16.68 \\
Palmiloleic acid (C16:1) & 0.21 & 0.15 & 0.24 & 0.19 & 0.15 & 0.17 \\
Stearic acid (C18:0) & 1.50 & 1.51 & 1.32 & 1.46 & 1.49 & 1.36 \\
Oleic acid (C18:1) & 43.31 & 47.35 & 42.73 & 43.44 & 47.12 & 43.03 \\
Linoleic acid (C18:2) & 34.13 & 28.49 & 36.14 & 33.58 & 28.54 & 35.28 \\
Arachidic acid (C20:0) & 0.56 & 0.58 & 0.39 & 0.65 & 0.56 & 0.43 \\
Eicosenoic acid (C20:1) & 0.40 & 0.42 & 0.38 & 0.42 & 0.42 & 0.43 \\
Linolenic acid (C18:3) & 1.12 & 1.47 & 1.72 & 1.09 & 1.54 & 1.70 \\
Behenic acid (C22:0) & 0.18 & 0.19 & 0.14 & 0.42 & 0.24 & 0.24 \\
Erucic acid (C22:1) & $\mathrm{ND} 2)$ & 0.05 & $\mathrm{ND}$ & $\mathrm{ND}$ & $\mathrm{ND}$ & $\mathrm{ND}$ \\
Lignoceric acid (C24:0) & 0.23 & 0.26 & 0.23 & 0.67 & 0.35 & 0.40 \\
Saturated fatty acid (SFA) & 20.82 & 22.08 & 18.79 & 21.28 & 22.24 & 19.40 \\
\hline Unsaturated fatty acid (UFA) & 79.18 & 77.92 & 81.21 & 78.72 & 77.76 & 80.60 \\
\hline UFA/SFA & 3.80 & 3.53 & 4.32 & 3.70 & 3.50 & 4.16 \\
\hline
\end{tabular}

${ }^{11}$ S-BRB, superctitical extract of Bukkyeong 2012-2 rice bran; S-JRB, superctitical extract of Jasmin 85 rice bran; S-HRB, superctitical extract of hanahreum rice bran; H-BRB, hexane extract of Bukkyeong 2012-2 rice bran; H-JRB, hexane extract of Jasmin 85 rice bran; H-HRB, hexane extract of hanahreum rice bran. 
58.46-59.30 g으로 나타나 핵산 추출한 미강 추출물보다 높게 나타났으며, 초임계 유체 추출한 한아름 미강 추출물 (S-HRB)의 요오드가가 가장 높았다. 산가, 과산화물가, TBA가의 경우, 핵산을 이용한 미강 추출물은 초임계 유체 를 이용한 미강 추출물보다 낮게 나타났으며, 품종에 따라 서는 자스민 미강 추출물(H-JRB)의 산가 및 과산화물가가 가장 낮게 나타났다. TBA가는 한아름 미강 추출물(H-HRB) 에서 각각 $71.33 \mathrm{mg} / \mathrm{kg}$ 으로 가장 낮게 나타났다. 초임계 및 핵산을 이용하여 추출한 미강 추출물의 토코페롤 함량은 북경 $(10.20,10.63 \mathrm{~g} / 100 \mathrm{~g})$ 이 가장 높은 함량을 나타내었고, 그 다음으로 한아름 $(8.30,7.35 \mathrm{~g} / 100 \mathrm{~g})$ 및 자스민 $(4.85,6.94$ $\mathrm{g} / 100 \mathrm{~g})$ 으로 나타나 추출 방법 및 품종에 따른 함량 차이가 있었다. 초임계 유체 및 핵산을 이용하여 추출한 미강 추출 물은 oleic $\operatorname{acid}(\mathrm{C} 18: 1)$, linoleic $\operatorname{acid}(\mathrm{C} 18: 2)$ 및 palmitic $\operatorname{acid}(\mathrm{C} 16: 0)$ 순으로 함량이 많았으며, 전체 지방산의 $95 \%$ 정도의 비율을 나타내었다. 추출방법에 따라서는 초임계 유체 추출한 미강 추출물의 불포화지방산 함량이 핵산 추출 한 미강 추출물보다 높은 것으로 확인되었다. 이러한 결과 에서, 초임계 유체 추출한 북경 및 한아름 미강 추출물 (S-BRB, S-HRB)의 가공적성 및 기능성 소재로서의 활성 가능할 것으로 판단된다.

\section{감사의 글}

본 연구는 농촌진흥청 어젠다사업(과제번호. PJ011647032018) 의 연구비 지원에 의해 연구되었으며, 이에 감사드립니다.

\section{References}

1. Chae GY, Kwon RH, Jang MW, Kim MJ, Ha BJ (2011) Whitening and antioxidative effect of rice bran fermented by Bacillus subtilis. J Soc Cosmet Scientists Korea, 37, 153-159

2. Lee YH, Moon TW (1994) Composition, water-holding capacity and effect on starch retrogradation of rice bran dietary fiber. Korean J Food Sci Technol, 26, 288-294

3. Bae SM, Kim JH, Cho CW, Jeong TJ, Yoon HS, Byun MW, Lee SC (2002) Effect of $\gamma$-irradiation on the antioxidant activity of rice hull, rice bran and barley bran. J Korean Soc Food Sci Nutr, 31, 246-250

4. Choi SP, Kang MY, Nam SH (2004) Inhibitory activity of the extracts from the pigmented rice brans on inflammatory reactions. J Korean Soc Appl Biol Chem, 47, 222-227

5. Lee KY, Kim JH, Son JR, Lee JS (2001) Detection and extraction condition of physiological compounds from bran of Heugjinju rice (Oryza sativa L.). Korean $\mathrm{J}$ Postharvest Sci Technol, 8, 296-301

6. Ha TY, Han S, Kim SR, Kim IH, Lee HY, Kim HK (2005) Bioactive components in rice bran oil improve lipid profiles in rat fed a high-cholesterol diet. Nutr Res, 25, 597-606

7. Chen CW, Cheng HH (2006) A rice bran oil diet increases LDL-receptor and HMG-CoA reductase RNA expressions and insulin sensitivity in rats with streptozotocin / Nicotinamide-induced type 2 diabetes. J Nutr, 136, 1472-1476

8. Koh JH, Yu KW, Suh HJ (2002) Biological activities of Saccharomyces cerevisiae and fermented rice bran as additives. Lett Appl Microbiol, 35, 47-51

9. Kim HY, Kim JH, Yang SB, Hong SG, Lee SA, Hwang SJ, Shin KS, Suh HJ, Park MH (2007) A polysacchairde extracted from rice bran fermented with Lentinus edodesenhances Natural Killer cell activity and exhibition anticaner effects. J Med Food, 10, 25-31

10. Nam SH, Choi SP, Kang MY, Koh HJ, Kozukue N, Friedman M (2005) Bran extracts from pigmented rice seeds inhibit tumor promotion in lymphoblastoid B cells by phorbol ester. Food Chem Toxicol, 43, 741-745

11. Oh SK, Kim DJ, Chun AR, Yoon MR, Kim KJ, Lee JS, Hong HC, Kim YK (2010) Antioxidant compounds and antioxidant activities of ethanol extracts from milling by-products of rice cultivars. J Korean Soc Food Sci Nutr, 39, $624-630$

12. Hong SG (2005) Development of immunostimulation materials from rice bran. Food industry and Nutrition, $10,42-47$

13. Lee JH, Oh SK, Kim DJ, Yoon MR, Chun AR, Choi IS, Lee JS, Kim YG (2013) Comparison of antioxidant activities by different extraction temperatures of some commercially available cultivars of rice bran in korea. J Korean Soc Food Sci Nutr, 26, 1-7

14. Kim YS, Ha TY, Lee SH, Lee HY (1997) Properties of dietary fiber extract from rice bran and application in bread-making. Korean J Food Sci Technol, 29, 502-508

15. Jang KH, Kwak EJ, Kang WW (2010) Effect of rice bran powder on the quality characteristics of cookie. Korean J Food Preserv, 17, 631-636

16. Aggarwal B, Sundaram C, Prasad S, Kannappan R (2010) Tocotrienols, the vitamin $\mathrm{E}$ of the 21st century: its potential against cancer and other chronic diseases. Biochem Pharmacol, 80, 1613-1631 
17. Park HS, Choi KM, Han GD (2008) Changes of bread making characteristics with the addition of rice bran, fermented rice bran and rice bran oil. J Korean Soc Food Sci Nutr, 37, 640-646

18. Park HS, Han GD (2008) Characteristics of breadmaking according to the addition of fermented rice bran. J Korean Soc Food Cult, 23, 62-67

19. Choi SW, Chung US, Lee KT (2005) Preparation of high quality grape seed oil by solvent extraction and chemical refining process. Korean J Food Preserv, 12, 600-607

20. Jung SH, Chang KS, Ko KH (2004) Physiological effects of curcumin extracted by supercritical fluid from turmeric (Curcuma longa L.). Korean J Food Sci Technol, 36, 317-320

21. Kim IH, Yoon SW, Lee JS, Lee JS (2013) Concentration of rice bran lipid soluble bioactive substances using supercritical carbon dioxide. Food Eng Prog, 17, 362-368

22. Ministry of Food and Drug Safety (2019) Korea Food Standards Codex, Seoul, Korea, p 263

23. AOCS (1990) Official and Tentative Methods of the American Oil Chemists' society. $15^{\text {th }}$ ed, American Oil Chemist's Society Press, Champaign, IL, USA, AOCS Official Method Ce 1-62

24. Tarladgis BG, Watts BM, Yunathan MT, Dugan Jr L (1960) A distillation method for the quantitative determination of malonaldehyde in ranced foods. J Am Oil chem, 37, 44-48

25. Lee MJ, Cho MK, Oh SH, Oh CH, Choi DS, Woo JW, Jung MY (2014) Fatty acid composition, contents of tocopherols and phytosterols, and oxidative stability of mixed edible oil of perilla seed and rice bran oil. J Korean Soc Food Sci Nutr, 27, 59-65

26. AOAC (1990) Official Method of Analysis, $12^{\text {th }}$ ed, Association of official analytical chemists, Washington DC, USA, p 963

27. Choi ID (2010) Physicochemical properties of rice cultivars with different amylose contents. J Korean Soc Food Sic Nutr, 39, 1313-1319

28. Shin HK, Lee JH, Lee SK (2017) Characteristics of white pan bread with roasted rice bran. Korean J Food Sci Technol, 49, 401-407

29. Hwang GH, Yun HR, Jung HN, Choi OJ (2014) Quality characteristics of baguette using fermented rice bran sourdough. Korean J Food Cook Sci, 30, 307-316
30. Oh YT (1998) A study on the usability of used vegetable oil as a diesel substitute in diesel engine. J Korean Soc of Marine Engineering, 22, 481-488

31. Jeong DS, Nam BU, Jeong YJ (2009) Characteristics of iodine values and viscosities by blending of waste vegetable oil and diesel oil. J Korea Acad Industr Coop Soc, 10, 1648-1653

32. Shin SK, Kim HJ, Kim MR (2014) Effects of mulberry concentrate on lipid oxidation of Yackwa during its storage. Korean J Food Preserv, 21, 483-490

33. Kim JE, Lee S, Yoo KM, Lee KH, Kim KT, Lee MH, Hwang IK (2014) Quality characteristics of ginseng seed oil obtained by different extraction methods. J Korean Soc Food Sci Nutr, 43, 439-445

34. Yen GC, Shyu SL (1989) Oxidative stability of sesame oil prepared from sesame seed with different roasting temperatures. Food Chem, 31, 215-224

35. Botha BM (2004) The supercritical fluid extraction of avocado oil. S A Avocado Growers' Assoc Yrb, 27, 24-27

36. Nagendra Prasad MN, Sanjay KR, Shravya Khatokar M, Vismaya MN, Nanjunda Swamy S (2011) Health benefits of Rice Bran-A Review. J Nutr Food Sci, 1, 1-7

37. Gu YR ,Kim JH, Cho JH, Seo WD, Hong JH, Youn KS (2018) Physicochemical characteristics and antioxidant activities of rice bran extracts according to extraction solvent and cultivar. Korean J Food Preserv, 25, 668-675

38. Chun A, Lee YY, Kim DJ, Yoon MR, Oh SK, Choi IS, Hong HC (2013) Cultivar comparison on tocopherols, tocotrienols, and antioxidant compounds in rice bran. Korean J Crop Sci, 58, 367-375

39. Park KY, Kang CS, Cho YC, Lee YS, Lee YH, Lee YS (2003) Genotypic difference in tocopherol and tocotrienol contents of rice bran. Korean J Crop Sci, 48, $469-472$

40. Lee DJ, Lee JY (2003) Tocopherols and tocotrienols in cereal grains. Korean J Crop Sci, 48, 1-12

41. Kim JY, Lee KT (2009) Enzymatic synthesis of low trans fats using rice bran oil, palm stearin and high oleic sunflower seed oil. J Korean Soc Food Sci Nutr, 38, $470-478$ 